

JURNAL SEGARA

http://ejournal-balitbang.kkp.go.id/index.php/segara

ISSN : 1907-0659

e-ISSN : 2461-1166

Acreditation Number : 158/E/KPT/2021

\title{
MODELING OF PLASTIC DEBRIS PARTICLE TRAJECTORY DURING PRE AND POST RECLAMATION IN JAKARTA BAY
}

\author{
Edwin Apriyanta Winardi ${ }^{1}$, Mutiara Rachmat Putri ${ }^{1,2)}$, \\ Muhammad Reza Cordova ${ }^{3)}$, \& Agus Setiawan ${ }^{3)}$
}

\author{
1)Earth Science Study Program, Bandung Institute of Technology, Bandung, Indonesia \\ Jalan Ganesha No. 10, Bandung 40132. Email: edwinapriyanta16@gmail.com \\ ${ }^{2)}$ Oceanographic Research Group, Bandung Institute of Technology, Bandung, Indonesia \\ ${ }^{3}$ Research Center of Oceanography, National Research and Innovation Agency, Jakarta, Indonesia
}

Received: 24 August 2021; Revised: 21 December 2021; Accepted: 23 December 2021

\begin{abstract}
The primary source of environmental problems in Jakarta Bay's waters is the change in hydrodynamics caused by reclamation and land-derived waste from the 13 watersheds that discharge into the bay. In June and December 2006 and 2015, hydrodynamic and trajectory simulations were conducted in Jakarta Bay to determine the distribution of plastic debris in pre- and post-reclamation conditions. The hydrodynamic conditions and particle trajectory in Jakarta Bay were described numerically using the Hamburg Shelf Ocean Model (HAMSOM). Secondary tidal data and primary ADCP data are used to validate the simulation results. The distribution of plastic debris released during the simulation depicts a distribution that follows the monsoon pattern, moving west during the east monsoon and moving east in the west monsoon and spreading along the coastline in both conditions. The percentage of plastic debris increased by $21.42 \%$ in June and $4.07 \%$ in December. The increase in the percentage of plastic debris that remains in the waters of Jakarta Bay is due to a $0.03-0.05 \mathrm{~m} / \mathrm{s}$ decrease in current velocity following the formation of the reclamation island. Due to the decrease in current velocity within the bay, trajectory simulations indicate that plastic debris will take an additional $69.52-304.25$ hours to exit. The accumulation of plastic debris around the reclamation islands demonstrates that the islands act as waste traps, necessitating proper waste cleanup, particularly in the canal area and around the reclamation island.
\end{abstract}

Keywords : Hydrodynamic and trajectory model, plastic debris, reclamation, Jakarta Bay.

Corresponding author:

Jl. Pasir Putih I Ancol Timur, Jakarta Utara 14430. Email: edwinapriyanta16@gmail.com 


\section{INTRODUCTION}

Jakarta Bay is semi-enclosed water bordered by Gembong Estuary to the east, Tanjung Pasir to the west, and Jakarta City to the south. Jakarta Bay has an average depth of $9.9 \mathrm{~m}$ with an area of $514 \mathrm{~km}^{2}$ and coastline length of $72 \mathrm{~km}$ (Badan Pengelola Lingkungan Hidup (BPLHD) Provinsi Daerah Khusus Ibukota Jakarta, 2016; Sampono et al., 2012). Around 13 rivers flow through Tangerang City, Jakarta, and Bekasi, eventually flushing into the Jakarta Bay.

The increase in population can be associated with increased plastic debris produced in that area (Supangkat \& Herdiansyah, 2020; Zulfinar \& Sembiring, 2015). Jakarta City is the city closest to the coastal area modeled in the thirteen rivers. Furthermore, all sources of waste were recorded as a result of the area of Jakarta City. Jakarta, Bekasi and Tangerang are Indonesia's most densely populated City, with a population density of 15,900 people/ $/ \mathrm{km}^{2}, 14,317$ people $/ \mathrm{km}^{2}$ and 10,763 people $/ \mathrm{km}^{2}$ in 2019 and increasing every year (Badan Pusat Statistik Kota Bekasi, 2020; Badan Pusat Statistik Kota Tangerang, 2019; Badan Pusat Statistik Provinsi DKI Jakarta, 2021). For example, in 2006, the population density in DKI Jakarta Province was 13,499 people $/ \mathrm{km}^{2}$, and in 2015 it reached 15,328 people $/ \mathrm{km}^{2}$. The waste entering the Bantargerbang Integrated Waste Management Site (TPST) in 2011 - 2015 shows an increase in waste entering the TPST (Badan Pengelola Lingkungan Hidup (BPLHD) Provinsi Daerah Khusus Ibukota Jakarta, 2016; Dinas Lingkungan Hidup Provinsi DKI Jakarta, 2021). . In 2015, the waste entering the TPST was 6.419 tons per day, while in 2019 , it was 7.702 tons per day.

DKI Jakarta Province produces about 6.0008.000 tons of waste generated by the community and industry every day (Cordova \& Nurhati, 2019). Bekasi City produces $800-900$ tons of waste, and around 2500 tons of waste is produced from Tangerang City every day (Badan Pusat Statistik Kota Bekasi, 2016; Kementerian Lingkungan Hidup dan Kehutanan, 2021). The DKI Jakarta Sanitation Department can manage only $90 \%$ of waste. Therefore, $25 \%$ of unmanaged waste per day is dumped directly into 13 rivers that end up in Jakarta Bay Waters in Jakarta. Cordova \& Nurhati (2019) stated that the waste input from Bekasi River and Dadap River crossing Tangerang City is greater than the waste input from the rivers that pass through Jakarta. Plastics account for up to $54 \%$ of riverine litter. Therefore, $23 \pm 7.1$ tons of waste per day enter the bay, and $8.32 \pm 2.44$ tons are plastic (Cordova \& Nurhati, 2019). Based on these two things, it can be concluded that there is a dominance of plastic debris found in Jakarta Bay.
Jakarta Bay is an area affected by human activities, which is reclamation. The reclamation activity aims to build a waterfront city, expand the port area, and develop an industrial area (Setiawan, 2016). The reclamation activities carried out in Jakarta Bay are said to have 17 islands with a total area of $51.89 \mathrm{~km} 2$. In 2015, three reclamation islands known as the Island of $C, D$, and $G$ were constructed, and by DKI Jakarta Governor's Decree No. 1744/2018, the three islands known as Kita Coast Region, Bisa Coastal Region, and Bersama Coastal Region. The impact of reclamation in water changes in the marine environment, such as changes in ocean currents and the increase in marine debris, impacts marine ecosystems (Rositasari et al., 2017). reclamation activities may result in the accumulation of plastic debris in the canal connecting the reclamation islands.

There have been previous studies on plastic debris in Jakarta Bay. Setiawan et al. (2007) performed a numerical simulation of waste transport. Simulations in November 2005 - November 2006 show that the distribution of waste follows the pattern of monsoons. In the west monsoon, garbage spreads to the east, and garbage spreads to the west in the east monsoon. There are variations in waste accumulation in 1 year. In the east monsoon, waste accumulation occurs around Sunda Kelapa to Cengkareng.

Moreover, Setiawan (2016) conducted a hydrodynamic simulation of 17 planned reclamation islands in Jakarta Bay. The simulation results indicate that the bay's currents undergo changes in tidal current patterns and a slowing of current velocity in the vicinity of the reclamation island. The reclamation island, which is located near the river mouth, may cause siltation due to sedimentation. Additionally, Jasmin et al. (2019) conducted a study to determine the path taken by plastic debris in Jakarta Bay prior to and following reclamation. The research findings indicate that the reclamation island reduced the current velocity in the bay by $0.002-0.02 \mathrm{~m} / \mathrm{s}$. The effect of the reduced flow velocity is that plastic debris accumulates for a more extended period than it did prior to reclamation. Waste material was trapped and piled up between the canals that connect the reclamation islands due to the reclamation (Jasmin et al., 2019).

In light of these issues in Jakarta Bay, specifically plastic debris and reclamation, this study will examine the movement of plastic debris in the bay prior to and following reclamation. The Hamburg Shelf Ocean Model (HAMSOM) simulated ocean currents as the primary driver of plastic debris during the west and east monsoons in 2006 and 2015. In this study, the plastic debris particles originated from six estuaries. The estuaries are Angke, Pluit, Marina, Koja, Cilincing, and Marunda Estuary. 


\section{METHODOLOGY}

\section{Model Design}

The domain in this research is the waters of Jakarta Bay with coordinates $5^{\circ} 55^{\prime} 38.925^{\prime \prime}-6^{\circ} 8^{\prime} 23,931$ " South and $106^{\circ} 39^{\prime} 58.239^{\prime \prime}-107^{\circ} 1^{\prime} 28.249^{\prime \prime}$ East (Figure 1). Figure 1 shows the pre-reclamation and postreclamation bathymetry of Jakarta Bay, with the reclamation island shown by the figure's red box. The bathymetry of Jakarta Bay is silting around the reclaimed island up to 3.6 meters. The reclamation island and the mainland form a canal with a distance of $0.2-0.3 \mathrm{~km}$ and, the canals formed between reclamation islands are 0.1-0.15 km (Setiawan, 2016).

This research is divided into two stages: a hydrodynamic simulation and a trajectory simulation. Table 1 details the construction of the hydrodynamic model used in this study. This study examines three scenarios. The hydrodynamic simulation's first scenario makes use of tidal forces, while the second and third scenarios make use of tidal and monsoon wind forces. Assume that the tides each month relatively have the same amplitude and phase so that the hydrodynamic simulation with tidal generating forces has a similar pattern of ocean currents every month. The objective is to observe the tidal currents and plastic debris distribution in both conditions. Monsoons were added as an external force in the second and third scenarios to examine the effect of monsoons on the distribution of plastic debris.

Hydrodynamic simulations were conducted four times between 2006 and 2015: in June and December.

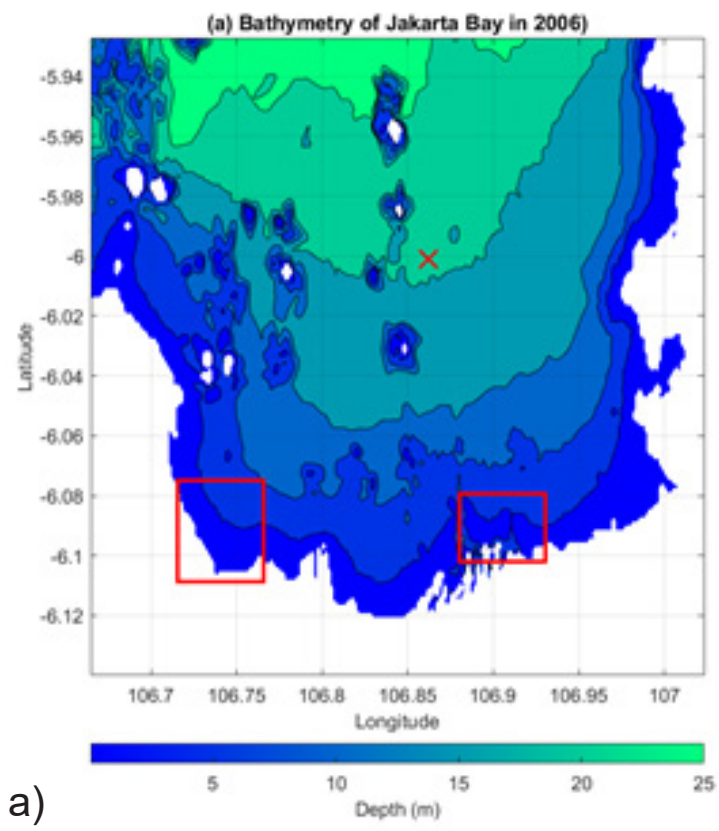

There are two possible outcomes and three possible conditions. Pre-reclamation is the first condition, and post-reclamation is the second. This study examines three distinct scenarios (Table 1). The first scenario is a simulation of both conditions in June 2006 and 2015 with tidal generating forces. The second scenario is a simulation in June 2006 and 2015 with constant southwesterly wind and tidal generating forces. In this scenario, the southwesterly winds are moving at a speed of $3.06 \mathrm{~m} / \mathrm{s}$ and $2.9 \mathrm{~m} / \mathrm{s}$, respectively. The third scenario is a hydrodynamic simulation performed in December 2006 and 2015 using a tidal generating force and a constant westerly wind at $2.5 \mathrm{~m} / \mathrm{s}$ and 1.8 $\mathrm{m} / \mathrm{s}$, respectively.

The results of the hydrodynamic model simulation are used as input to the trajectory model in the form of zonal ( $\mathrm{u}$ ) and meridional (v) velocity components; thus, the model domain used in trajectory simulation is identical to the hydrodynamic simulation domain (Table 1). Thus, the trajectory model's starting point is six estuaries and data collection locations for plastic debris, as shown in Table 2 and Figure 2.

0.1 ton-wet is assumed to be one particle in the trajectory simulation, resulting in the release of several particles of plastic debris data from each river estuary (Table 2). Plastic is assumed to have a lower density $\left(1.027 \mathrm{~kg} / \mathrm{m}^{3}\right)$ in this study than Jakarta's seawater density $\left(0.91 \mathrm{~kg} / \mathrm{m}^{3}\right)$. According to this assumption, the position of plastic particles during the simulation is close to sea level, as the density of plastic is less than that of Jakarta seawater. The plastic will be moved during the simulation solely due to the influence of

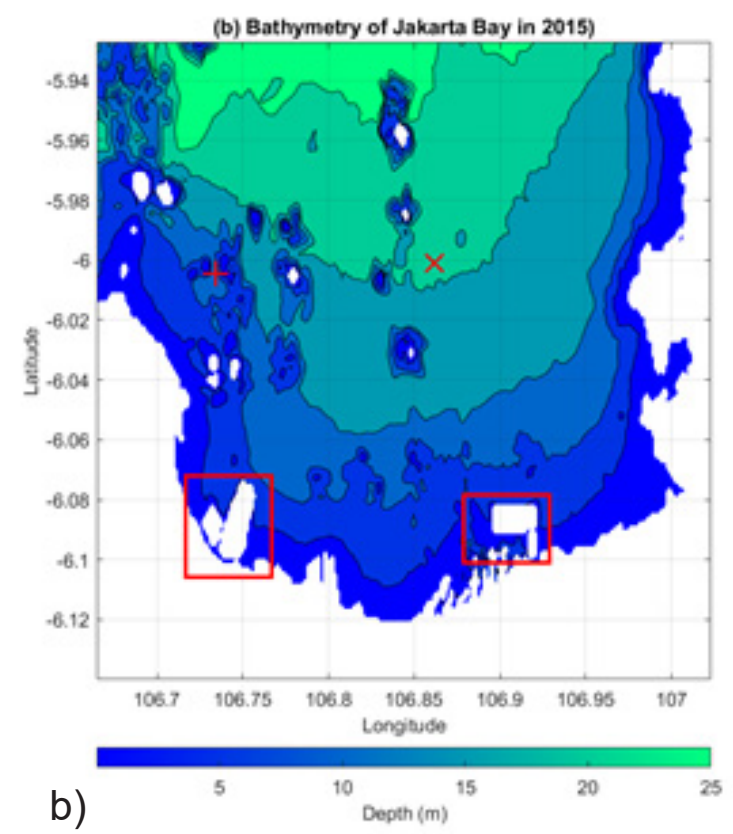

Figure 1. (a) Bathymetry of Jakarta Bay in 2006 (a); (b) and in 2015. Red boxes show the difference in pre and post-reclamation. Cross and plus symbols show the location for verification of elevation and ocean currents. 
Table 1.

. Hydrodynamic model design

\begin{tabular}{|c|c|}
\hline Parameter & Detail \\
\hline Domain & $5^{\circ} 55^{\prime} 38.925^{\prime \prime}-6^{\circ} 8^{\prime} 23.931^{\prime \prime} \mathrm{S}$ and $106^{\circ} 39^{\prime} 58.239^{\prime \prime}-107^{\circ} 1^{\prime} 28.249^{\prime \prime} \mathrm{E}$ \\
\hline Number of Grids & $154 \times 259$ \\
\hline Coordinate & $\begin{array}{l}\text { Cartesian coordinates in the horizontal layer with a space step of } 0.15 \mathrm{~km} \text { and } \mathrm{z} \\
\text { coordinates in the vertical direction with a space step of } 3 \mathrm{~m}\end{array}$ \\
\hline Time and Time Steps & $\begin{array}{l}720 \text { hours (June } 2006 \text { and 2015) \& } 744 \text { hours (December } 2006 \text { and 2015), } \\
\text { with a time step of } 60 \text { seconds }\end{array}$ \\
\hline Bathymetry & Bathymetry Map of the Indonesian Navy's Hydro-Oceanographic Service (DISHIDROS) \\
\hline Open Boundary & Tidal Elevation (M2, S2, K2, N2, K1, O1, P1, Q1, M4, MS4, and MN4) \\
\hline Scenario I & The tidal force of June 2006 and 2015 \\
\hline Scenario II & Tidal and uniform wind generating force from the southeast in June 2006 and 2015 \\
\hline Scenario III & Tidal and uniform wind generating force from the west in December 2006 and 2015 \\
\hline
\end{tabular}

Table 2.

Particle initial points in trajectory simulations (Cordova \& Nurhati, 2019; Setiawan et al., 2006)

\begin{tabular}{|c|c|c|c|c|c|c|c|}
\hline \multirow{3}{*}{ Estuary } & \multirow{3}{*}{ Color } & \multirow{3}{*}{ Latitude } & \multirow{3}{*}{ Longitude } & \multicolumn{4}{|c|}{ Total Weight of Garbage (ton-wet) } \\
\hline & & & & \multicolumn{2}{|c|}{2006} & \multicolumn{2}{|c|}{2015} \\
\hline & & & & June & December & June & December \\
\hline Angke & Red & $6^{\circ} 5^{\prime} 52.80^{\prime \prime} \mathrm{S}$ & $106^{\circ} 46^{\prime} 01.20^{\prime \prime} \mathrm{E}$ & 0.57 & 0.59 & 1.20 & 1.55 \\
\hline Pluit & Green & $6^{\circ} 6 ' 21.60 ” \mathrm{~S}$ & $106^{\circ} 47^{\prime} 02.40^{\prime \prime} \mathrm{E}$ & 1.90 & 1.96 & 0.76 & 1.04 \\
\hline Marina & Magneta & $6^{\circ} 6^{\prime} 47.45^{\prime \prime} \mathrm{S}$ & $106^{\circ} 51 ' 10.80 " \mathrm{E}$ & 0.42 & 0.43 & 0.88 & 1.15 \\
\hline Koja & Blue & $6^{\circ} 6 ' 19.80 " \mathrm{~S}$ & $106^{\circ} 54^{\prime} 25.20^{\prime \prime} \mathrm{E}$ & 1.03 & 1.07 & 1.25 & 1.51 \\
\hline Cilincing & Cyan & $6^{\circ} 5^{\prime} 55.08 " \mathrm{~S}$ & $106^{\circ} 56^{\prime} 13.20^{\prime \prime} \mathrm{E}$ & 0.99 & 1.03 & 0.91 & 1.58 \\
\hline Marunda & Yellow & $6^{\circ} 5^{\prime} 26.44 ” \mathrm{~S}$ & $106^{\circ} 57^{\prime} 10.80 ” \mathrm{E}$ & 2.33 & 2.41 & 1.18 & 1.56 \\
\hline
\end{tabular}
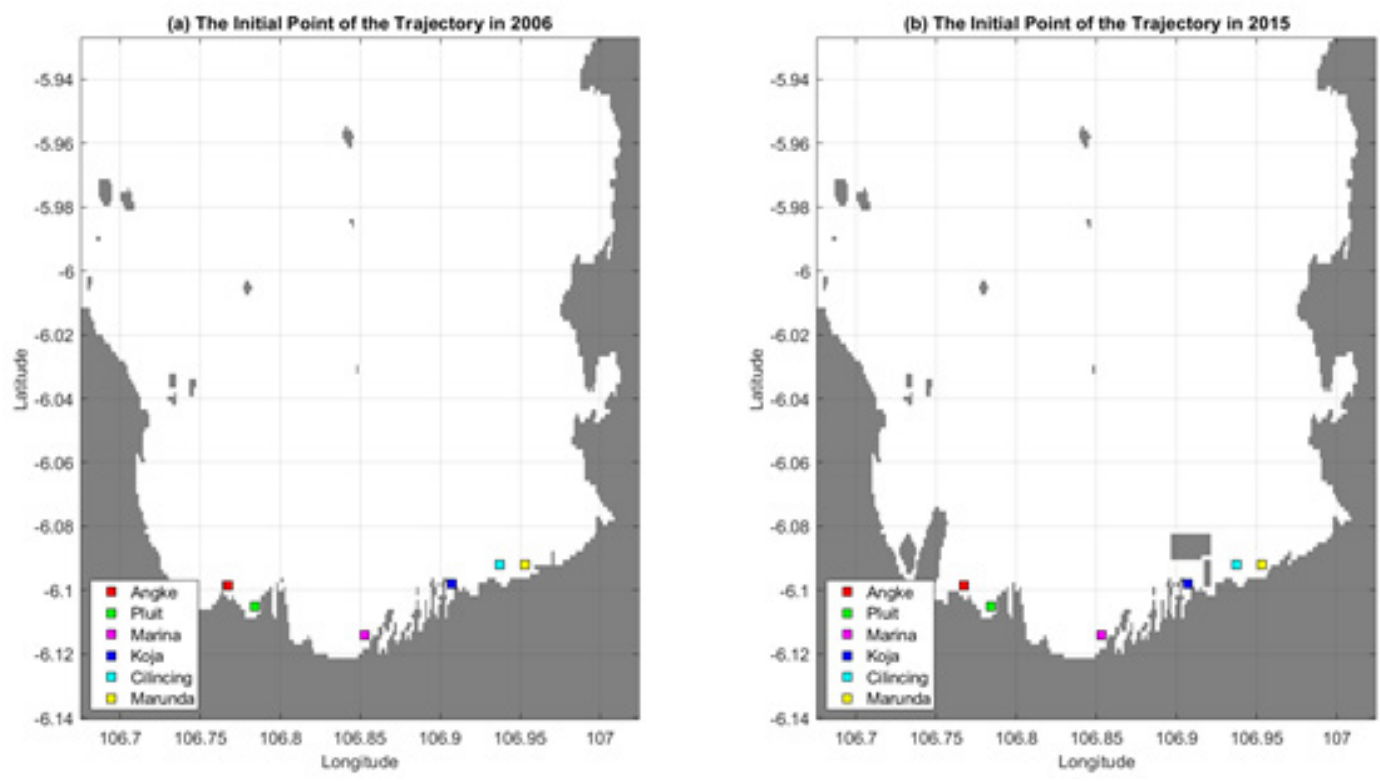

Figure 2. The initial point of the trajectory (a) in 2006; and (b) 2015.

advection, with buoyancy, density changes, and plastic fragmentation being ignored.

Figure 2 depicts the initial coordinates used to determine each river mouth's location in Table 2 . This study makes use of six rivers that run through DKI Jakarta Province. Plastic particles were released on 1 June and 1 December in the trajectory simulation. For the 2015 simulation, waste data were derived from
Cordova \& Nurhati's (2019) riverine plastic debris flow to Jakarta Bay, while for the 2006 simulation, waste data were derived from Setiawan et al. (2007) research results.

\section{Hydrodynamic Model}

HAMSOM was used as the numerical model in this hydrodynamic simulation. HAMSOM is a threedimensional baroclinic hydrodynamic model capable of 
solving primitive equations using a semi-implicit scheme, and it is a numerical model based on momentum and continuity of the $x, y$, and $z$ directions in Cartesian coordinates (Backhaus, 1985). Momentum equations and continuity equations that build this model are shown in Eq. (1) - (4). The terms $u, v$, and $w$ are components of the current velocity in the $x, y$, and $z$ - axes $(\mathrm{m} / \mathrm{s})$. The terms $x, y$ is the direction zonal, meridional, and z-direction to the depth. The term $f$ is the Coriolis parameter (radian/s); The term $\rho$ is the density of water $\left(\mathrm{kg} / \mathrm{m}^{3}\right)$. The term $P$ is the hydrostatic pressure $(\mathrm{Pa})$. The term $\mathrm{p}$ is atmospheric pressure $(P a)$. The term $A_{H}$ is the horizontal coefficient of eddy viscosity $\left(\mathrm{m}^{2} / \mathrm{s}\right)$. The term $A_{v}$ vertical coefficient of eddy viscosity $\left(\mathrm{m}^{2} / \mathrm{s}\right)$; and The terms $F_{x}, F_{y}$ are external forces such as disturbances in the $\mathrm{x}$ and $\mathrm{y}$ directions $\left(\mathrm{kg} \cdot \mathrm{m} / \mathrm{s}^{2}\right)$.

$$
\begin{aligned}
& \frac{\partial u}{\partial t}+u \frac{\partial u}{\partial x}+v \frac{\partial u}{\partial y}+w \frac{\partial u}{\partial z}-f v \\
& =-\frac{1}{\rho} \frac{\partial p}{\partial x}+A_{H} \nabla^{2} u+\frac{\partial}{\partial z}\left(A_{v} \frac{\partial u}{\partial z}\right)+F_{x} \\
& \frac{\partial v}{\partial t}+u \frac{\partial v}{\partial x}+v \frac{\partial v}{\partial y}+w \frac{\partial v}{\partial z}+f u \\
& =-\frac{1}{\rho} \frac{\partial p}{\partial y}+A_{H} \nabla^{2} v+\frac{\partial}{\partial z}\left(A_{v} \frac{\partial v}{\partial z}\right)+F_{y} \\
& \frac{\partial P}{\partial z}=-\rho g \\
& \frac{\partial u}{\partial x}+\frac{\partial v}{\partial y}+\frac{\partial w}{\partial z}=0
\end{aligned}
$$

The equation from HAMSOM is discretized using a semi-implicit finite difference method and the Arakawa C-Grid. Semi-implicit calculations are carried out to calculate the zonal, meridional velocity, advection, and depth diffusion terms. In addition, the horizontal advection and diffusion terms are calculated explicitly.

\section{Trajectory Model}

The trajectory model used is the model developed by Mayer (1985). The calculation of particle displacement from the starting point to the next point $\left(x_{1}\right.$ and $\left.x_{2}\right)$ can be calculated using Eq. (5). In Eq. (5), the term $u(x)$ is the velocity $u$ at the western boundary of the grid $\left(u_{w}\right)$ so that $u(x)$ can be written into Eq. (6). Eq. (5) integrated to $x_{2}$ and $x_{1}$ for the $d x$ term and $t+\Delta t$ and $t$ for the $d t$ term. The integrations of Eq. 5 give an equation for the advection displacement distance of the particles during the time interval dt from position $x_{1}$ to $x_{2}$ is shown in Eq. (7). Surface boundary conditions in the model this trajectory acts as a reflector.

$$
d x=u(x) d t
$$

$$
\begin{aligned}
& u(x)=u_{w}+x \frac{\partial u}{\partial x} \\
& x_{2}-x_{1}=\left(\frac{u_{w}}{\frac{\partial u}{\partial x}}+x_{1}\right)\left(e^{\frac{\partial u}{\partial x} \Delta t}-1\right)
\end{aligned}
$$

\section{Hydrodynamic Model Verification}

The hydrodynamic simulation verification was performed by comparing the Geospatial Information Agency (BIG) tidal predictions with the elevation simulation results. Elevation data from BIG was downloaded at coordinates $6^{\circ} 0^{\prime} 3,27$ " $S$ dan $106^{\circ} 51^{\prime}$ 43,24" E in June and December 2006 and 2015 (Figure 1). The root mean square error (RMSE) can be calculated by squaring the error (simulation results minus the predicted data) divided by the amount of data.

The hydrodynamic simulation results are also compared with current data from the Acoustic Doppler Current Profiler/ADCP at coordinates 6 ${ }^{\circ} 2$ ' 26.15" S and $106^{\circ} 44^{\prime} 3.14$ " E. Flow data was taken on 2-7 June 2015 from the Ministry of Public Works. Hydrodynamic simulation results in the first and second scenarios in 2015 compared with the data stream filtered field before and after filtered by the four main tidal components $\mathrm{M} 2, \mathrm{~S} 2, \mathrm{~K} 1$, and $\mathrm{O} 1$.

\section{RESULTS AND DISCUSSION}

\section{Hydrodynamic Model Verification}

Elevation comparisons between simulation results and tidal predictions indicate that with a tidal range of $1 \mathrm{~m}$, the magnitude and phase values are relatively constant, indicating that these are classified as diurnal tides (Figure 3). The simulation results have a correlation value of $95.79-97.17 \%$ with the tidal prediction from BIG with an RMSE value of 7.19 - $8.90 \mathrm{~cm}$. The correlation value is close to 1 or $100 \%$, and the RMSE value is minimal compared to the tidal riding value of $0.99-1.23$ meters, indicating that the hydrodynamic simulation has described the tidal conditions in Jakarta Bay.

Current data measured using ADCP on 2-7 June 2015 at coordinates $6^{\circ} 2^{\prime} 26.15^{\prime \prime}$ and $106^{\circ} 44^{\prime} 3.14^{\prime \prime}$ E or around Bidadari Island was used to compare simulation results of scenarios I and II. The current depiction of the ADCP data and the simulation results is shown in Figure 4.a, where the current direction of the simulation results and the ADCP's data show a relatively similar direction. The direction of the currents is relatively the same as shown at flood tide, where the current in these conditions moves to the northwestward, and at ebb tide, the current moves relatively to the southeastward. 



Figure 3. Comparison of BIG tidal predictions with: (a) elevation simulation June 2006 (b) simulation elevation June 2015; (c) simulation elevation December 2006; (d) December 2015 simulation elevation.

At ebb tide, ADCP detects a current flowing southwestward, whereas the simulated current flows southeastward. Due to this direction difference, ADCP currents are filtered using a band-pass filter with frequencies between principal tidal components, namely $\mathrm{M} 2, \mathrm{~S} 2, \mathrm{~K} 1$, and $\mathrm{O} 1$. Figure $4 . \mathrm{b}$ shows the current depiction that has been filtered to include the simulation results. The simulation results indicate a relatively similar direction to that of the ADCP current when filtered against the tidal component as depicted by the current. On this basis, it can be concluded that the results of the hydrodynamic simulation of currents in Jakarta Bay using tidal and wind-generating forces accurately describe current conditions in the bay.

\section{Ocean Currents in Jakarta Bay Pre and Post Reclamation}

The hydrodynamic simulation results for the first scenario are depicted in Figures 5.a and 5.b. Sea surface currents in Jakarta Bay flow east to the southeast into the bay during flood tides and north to the west out of the bay during ebb tides. Currents along the coast run relatively parallel to the shoreline. The current pattern in Jakarta Bay did not significantly change in either condition due to the three reclamation islands. However, due to the reclamation island formation, the

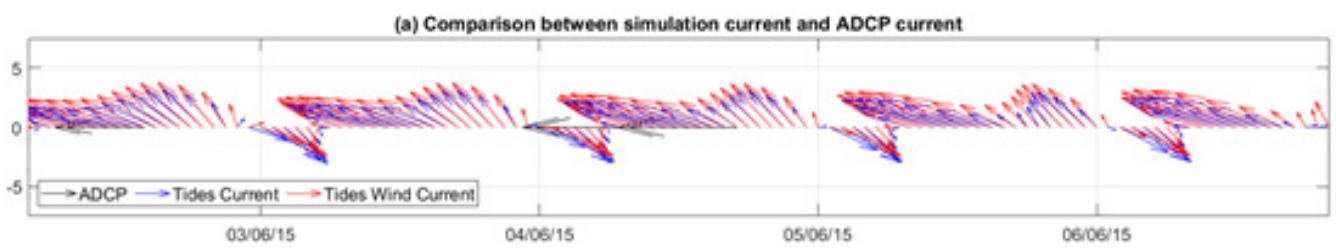

(b) Comparison between simulation current and filtered $A D C P$ current with main tidal component

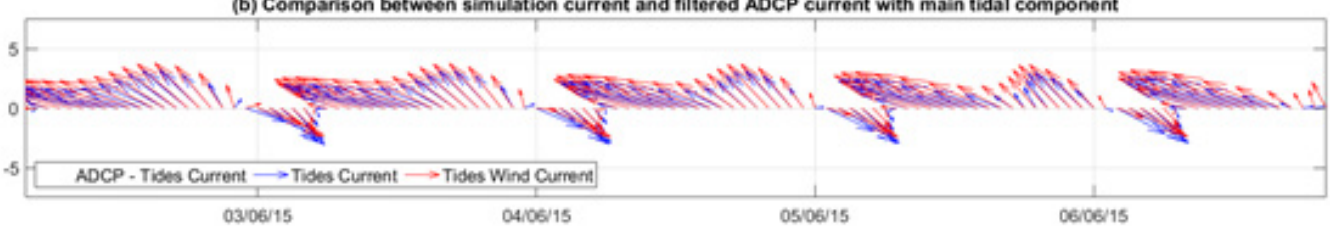

(c) Simulated water level elevation on 2-7 June 2015

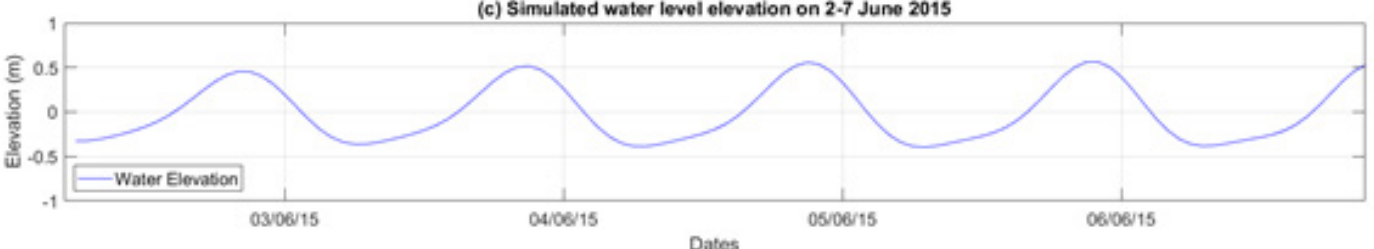

Figure 4. Comparison between simulation current and: (a) ADCP current; (b) filtered ADCP current with the main tidal component; (c) simulated water level elevation on 2 - 7 June 2015. 
average current speed and direction around the Kita, Bisa, and Bersama Coastal Areas have decreased. The average current in the Kita and Bisa Coastal Areas shifted from moving eastward at an average speed of $0.032 \mathrm{~m} / \mathrm{s}$ in 2006 to moving around the two coastal areas at an average speed of $0.002 \mathrm{~m} / \mathrm{s}$ in 2015 .

The hydrodynamic simulation results in the second scenario are shown in Figures 5.c and 5.d. The currents in both conditions show relatively the same direction of movement where the currents move on average from west to southwest. What distinguishes the two conditions is the speed and direction of current movement around the reclamation island. At the time of pre-reclamation, the current velocity showed an average of $0.0291 \mathrm{~m} / \mathrm{s}$. At the time of post-reclamation, the average current speed of $0.0264 \mathrm{~m} / \mathrm{s}$. Thus, the current around the reclamation island shows a change where the current is divided into two in the post-reclamation condition-first, the current moves

(a) Average Currents Scenario I June 2006

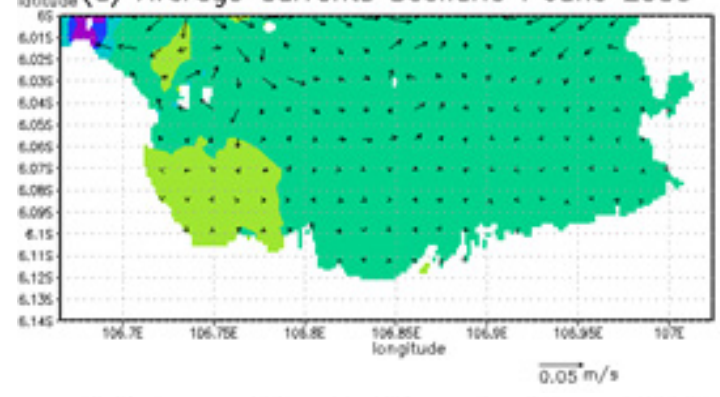

fol (c) Average Currents Scenario II June 2006

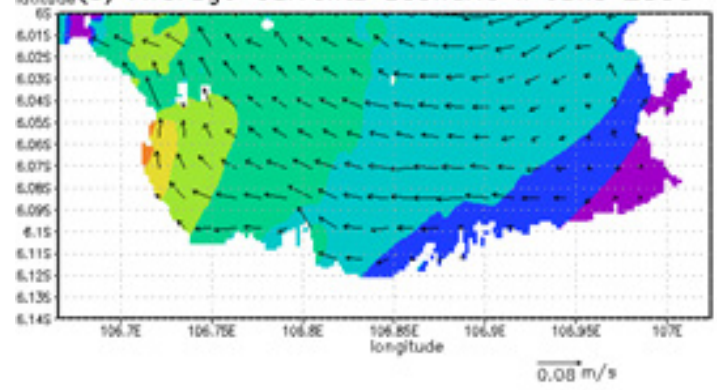

(e) Average Currents Scenorio III Dec 2006

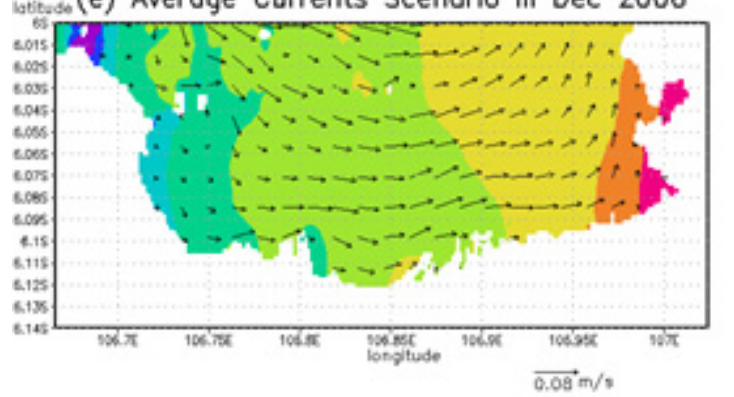

northward and then around the reclaimed island, and the second, the current that moves southward, moves in the canal formed between the reclaimed island and the mainland.

The results of the hydrodynamic simulations for the third scenario are depicted in Figures 5.e and 5.f. In December, the simulation results indicate that the current moves eastward, away from the domain, towards Muara Gembong. The distinction between the two conditions (pre- and post-reclamation) yields the same results as the previous two scenarios. The reclamation of the island reduced the bay's maximum current velocity to $0.06 \mathrm{~m} / \mathrm{s}$ from $0.08 \mathrm{~m} / \mathrm{s}$. Currents flow in two directions around the reclamation island: northward and southward, passing through the canals formed between the reclamation island and the mainland.

The hydrodynamic simulations in these three

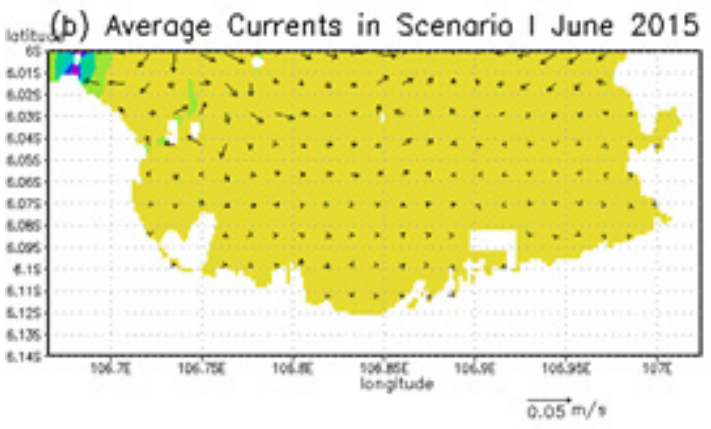

(d) Average Currents Scenario II June 2015

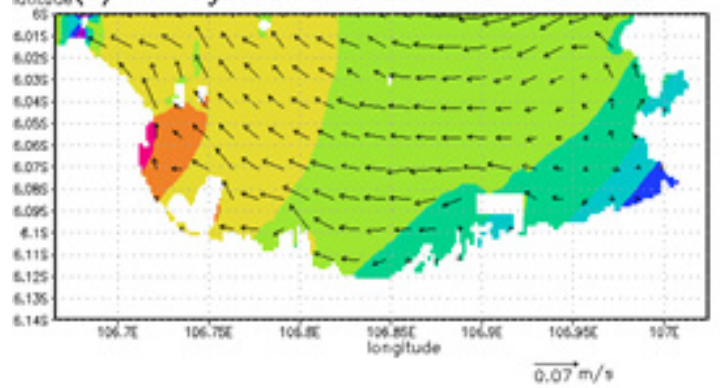

(f) Average Currents Scenario III Dec 2015

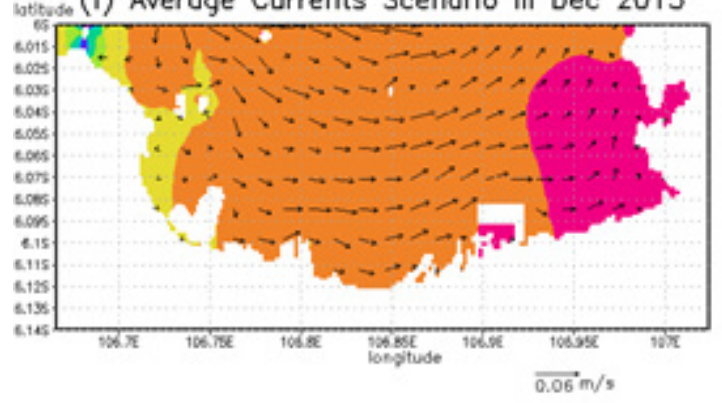

Figure 5. Average currents in Jakarta Bay in the scenario I in : (a) June 2006 and (b) June 2015 (b); in scenario II in (c) June 2006, (d) June 2015 ; and in scenario III (e) December 2006 and (f) December 2015. 
scenarios are consistent with the findings of Setiawan et al. (1998 and 2007), who found that the surface current in Jakarta Bay moves in the direction of the monsoon wind. According to the simulation results, the current generated by the tides and wind has a higher current velocity than the tidal current. According to the simulation results, local factors, specifically monsoons, have a more significant influence on the direction and magnitude of ocean currents in Jakarta Bay than tides do. This statement is consistent with previous research findings.

Numerous conclusions can be drawn from the simulation results for these three scenarios in two conditions. The first is that the current in Jakarta Bay is weaker post-reclamation than it was before. The second point is that the overall current pattern does not differ significantly between the two conditions, except in the reclamation area, where ocean currents surround the reclamation island.

\section{Plastic Debris Trajectory in Jakarta Bay}

The first scenario depicts plastic debris particles moving relative to the east from the point where they were released (Figure 6.a and Figure 6.b). The particles are pushed to the east by tidal asymmetry. Figure 4.c illustrates the asymmetry of the tides in Jakarta Bay, with the flood tide lasting longer than the ebb tide. The preceding flood tide, which lasts between 8 and 15 hours per day, demonstrates the movement of currents entering the bay and moving eastward, causing the plastic particles in the first scenario to move relative eastward. In both cases, the released particles do not
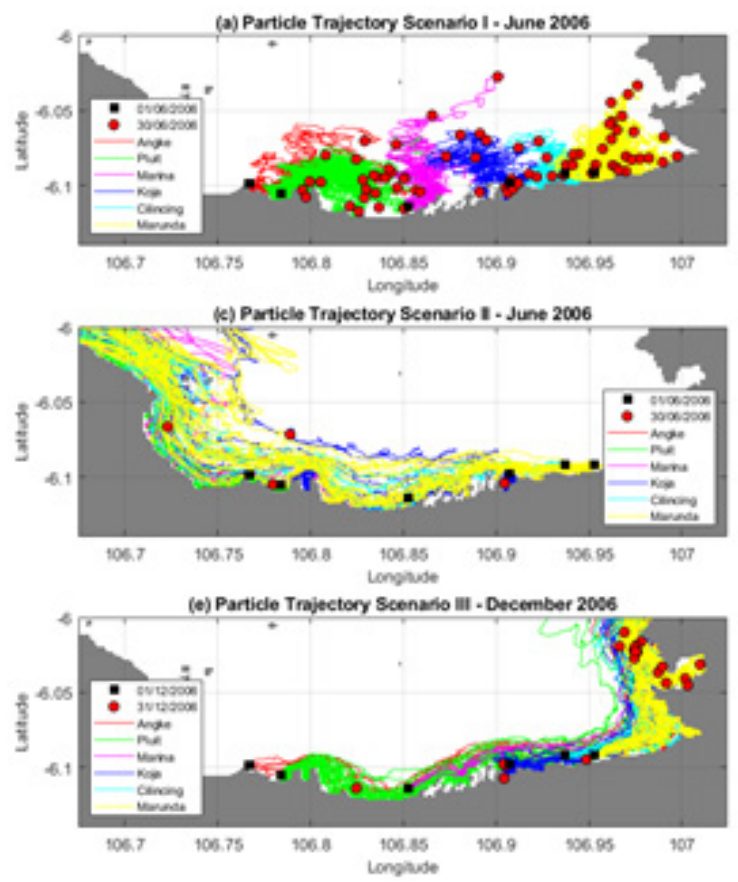

appear to be outside the study area's domain.

In the first scenario, the difference between the two conditions is the displacement of the entire released particle. The particle path line in Figure 4.b with the reclamation island is shorter in 2015 than in 2006. The displacement of particles released from the six rivers demonstrates a decrease in displacement as the current velocity in Jakarta Bay decreases (Table $3)$. In 2015, the displacement decreased by 0.19-0.33 kilometers, demonstrating the effect of reclamation islands on the distribution of plastic debris in Jakarta Bay.

Figures 6.c and 6.d illustrate the results of the particle trajectory simulation for the second scenario under both conditions. Plastic debris moves westward in the second scenario, following the average surface current. In contrast to the first scenario, the second scenario simulation shows plastic debris coming out of the study domain $6^{\circ} 00^{\prime} 00^{\prime \prime}-6^{\circ} 8^{\prime} 23.931^{\prime \prime} S$ and $106^{\circ} 39^{\prime}$ $58.239^{\prime \prime}-107^{\circ} 1^{\prime} 28.249^{\prime \prime} E$ at the western boundary of the domain. A total of 7.2 tons of plastic debris were released in June 2006; 6.8 tons or $94.44 \%$ of plastic debris left Jakarta Bay at the end of the simulation, while in June $2015 ; 4.6$ tons of 6.3 tons or $73.02 \%$ of plastic debris left in Jakarta Bay at the end of the simulation (Table 4). Post-reclamation, there is an increase in the plastic debris left in Jakarta Bay by $21.42 \%$.

After the second scenario simulation, the distribution of plastic debris demonstrates a difference in plastic debris distribution. At the final result of the
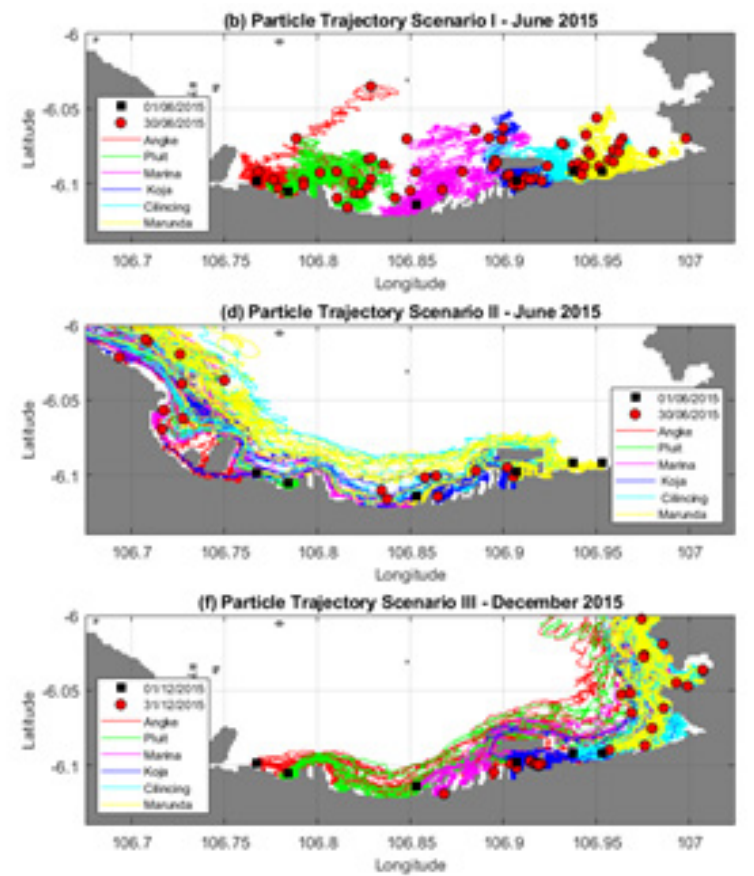

Figure 5. $\quad$ Particle trajectory in Jakarta Bay scenario I (a) in June 2006 and (b) June 2015; scenario II in (c) June 2006and (d) June 2015; scenario III in (e) December 2006 (e) and (f) December 2015. 
Table 3.

Average particle displacement (in $\mathrm{km}$ ) for the three scenarios

\begin{tabular}{lllllll}
\hline & \multicolumn{2}{l}{ Scenario I } & \multicolumn{2}{l}{ Scenario II } & \multicolumn{2}{l}{ Scenario III } \\
\cline { 2 - 7 } & $\mathbf{2 0 0 6}$ & $\mathbf{2 0 1 5}$ & $\mathbf{2 0 0 6}$ & $\mathbf{2 0 1 5}$ & $\mathbf{2 0 0 6}$ & $\mathbf{2 0 1 5}$ \\
\hline Angke & 7.43 & 4.70 & 15.36 & 14.63 & 26.85 & 24.04 \\
Pluit & 5.33 & 4.32 & 17.07 & 17.94 & 22.54 & 23.17 \\
Marina & 6.64 & 4.30 & 24.14 & 23.80 & 21.26 & 15.01 \\
Koja & 1.99 & 1.24 & 22.28 & 15.50 & 15.47 & 9.121 \\
Cilincing & 1.93 & 2.26 & 31.67 & 26.63 & 17.60 & 14.676 \\
Marunda & 3.00 & 2.29 & 32.29 & 31.21 & 15.31 & 15.82 \\
\hline
\end{tabular}

Table 4.

Distribution of plastic debris at the initial and end of the simulation in Jakarta Bay

\begin{tabular}{lllll}
\hline & & $\begin{array}{l}\text { Initial } \\
\text { (ton) }\end{array}$ & $\begin{array}{l}\text { End } \\
\text { (ton) }\end{array}$ & $\begin{array}{l}\text { Total Plastic DebrisLeft } \\
\text { the Domain (ton) }\end{array}$ \\
\hline Scenario I & 2006 & 7.2 & 7.2 & 0.0 \\
& 2015 & 6.3 & 6.3 & 0.0 \\
Scenario II & 2006 & 7.2 & 0.4 & 6.8 \\
& 2015 & 6.3 & 1.7 & 5.1 \\
Scenario III & 2006 & 7.5 & 1.9 & 5.6 \\
& 2016 & 8.5 & 2.5 & 6.0 \\
\hline
\end{tabular}

simulation, 0.3 tons of abundant plastic debris was spread around Bidadari Island, and 0.1 tons of waste from the Koja Estuary became stuck near the port in 2006. Meanwhile, 1.7 tons of plastic debris remained in 2015 or post-reclamation after the simulation. In 2015, plastic debris was concentrated in the northwest Kita Coastal Area, with approximately 0.9 tons of waste and approximately 0.8 tons of plastic debris scattered throughout Bersama Coastal Area and Ancol Beach.

At the simulation's ending, the amount of plastic debris remaining in June 2015 was more significant than in June 2006, indicating that the reclamation island affects the distribution of plastic debris in Jakarta Bay. The average residence time of the simulated particles is shown in Table 5. The table indicates that the residence time required for particles to leave the domain was significantly longer in June 2015 than in June 2006. Between June 2006 and June 2015, residence time increased by 69.52 hours to 189.75 hours.

In scenario III, the trajectory simulation depicts the movement of particles eastward and then around the coast to the Gembong Estuary. These particles move in the same direction as the average current in December, which is eastward. The trajectory simulation results for scenario III are similar to scenario II: an increase in particle residence time in December 2015 compared to December 2006. Between June 2006 and June 2015, the length of stay increased by 99 - 304.25 hours. At the end of the simulation in December 2006, about 1.9 tons or 7.5 tons or $25.34 \%$ of plastic debris was in the bay, and the rest of the plastic debris left Jakarta Bay. In December 2015, there were still 2.5 tons of the 8.5 tons or $29.41 \%$ of plastic debris in the bay. The amount of remaining plastic debris that increased by $4.08 \%$ in 2015 compared to 2006 shows that the reclamation island makes it more difficult for plastic debris to get out of the bay.

The distribution of plastic debris in December 2015 shows the distribution along the coast from Marina to Gembong Estuary or the northeastern boundary of the study domain. In December 2006, the distribution of plastic debris ended around Cikarang and Keramat Estuary (6 ${ }^{\circ} 00^{\prime} 23,167^{\prime \prime} \mathrm{S}$ and 106 ${ }^{\circ} 59^{\prime} 30,674 " \mathrm{E}$ ). The area around Koja Estuary can be seen from the accumulation of garbage around the Joint Beach. The

Table 5.

Average times require (in hours) for plastic debris particles to leave Jakarta Bay

\begin{tabular}{lllll}
\hline & \multicolumn{2}{l}{ Scenario II } & \multicolumn{2}{l}{ Scenario III } \\
& $\mathbf{2 0 0 6}$ & $\mathbf{2 0 1 5}$ & $\mathbf{2 0 0 6}$ & $\mathbf{2 0 1 5}$ \\
\hline Angke & 176.00 & 365.75 & 488.33 & 661.13 \\
Pluit & 279.47 & 349.00 & 563.55 & 663.40 \\
Marina & 372.75 & 469.78 & 379.00 & 683.25 \\
Koja & 595.50 & 692.69 & 539.10 & 699.67 \\
Cilincing & 431.80 & 545.00 & 269.90 & 427.69 \\
Marunda & 456.52 & 592.17 & 375.09 & 327.86 \\
\hline
\end{tabular}


plastic debris amounted to 0.3 tons in Muara Koja and amounted to 0.3 tons in Muara Koja and increased to 0.8 tons of garbage trapped in the waters. In addition, plastic debris from Muara Marina and Angke is trapped between Marina and Koja. These two things prove that the reclamation island acts like a plastic debris trap.

\section{CONCLUSION}

The plastic debris in Jakarta Bay exhibits a seasonal distribution. For instance, during the west monsoon, the plastic will eventually move eastward relative to the west monsoon and vice versa. The trajectory simulation of three scenarios in both conditions demonstrates that the reclamation island affects the plastic distribution in Jakarta Bay. The reclamation island has affected the currents in Jakarta Bay, with the currents surrounding the reclamation island decreasing compared to pre-reclamation times. Due to the decrease in current velocity, plastic debris takes approximately 69.52 to 189.75 hours longer to leave Jakarta Bay in June and 99.85 to 304.25 hours longer in December. At the conclusion of the simulation, it is demonstrated that the amount of plastic debris in the post-reclamation condition is significantly more tremendous than in the pre-reclamation condition. The simulation concludes with a percentage increase in the plastic of $21.42 \%$ in June and $4.0 \%$ following reclamation.

Additionally, the simulation results indicate that plastic debris has accumulated near the reclamation island. As a result, there is a risk of plastic debris accumulating in the canals connecting the Reclamation islands. According to this research, waste in Jakarta Bay should be cleaned regularly, particularly around the reclamation island, to avoid silting up the newly formed canals.

\section{ACKOWLEDGEMENTS}

This research was a part of the project titled "Marine Science \& Technology Cooperation between Korea and Indonesia (20180319)" and "Ocean and Coastal Basic Survey and Capacity Enhancement in Cirebon, Indonesia (G52440)" funded by the Ministry of Oceans and Fisheries, Korea And it was part of the "Numerical Assessment of Coastal Environmental for the New Capital City Plan of the Republic of Indonesia in Balikpapan Bay, East Kalimantan" research as a lesson for planning a new capital city.

\section{REFFERENCE}

Backhaus, J.O. (1985). A three-dimensional model for the simulation of shelf sea dynamics. Deutsche Hydrografische Zeitschrift, 38(4), 165-187. https:// doi.org/10.1007/BF02328975
Badan Pengelola Lingkungan Hidup (BPLHD) Provinsi Daerah Khusus Ibukota Jakarta. (2016, in Indonesian). Report on the Environmental Status of the Province of the Special Capital Region of Jakarta in 2015.

Badan Pusat Statistik Kota Bekasi. (2016, in Indonesian). Tonnage and Volume of Waste Entering the Bekasi City Sumur Batu TPA in 2015. https://bekasikota. bps.go.id/statictable/2016/12/19/42/tonase-danvolume-sampah-yang-masuk-ke-tpa-sampahsumur-batu-kota-bekasi-tahun-2015-.html

Badan Pusat Statistik Kota Bekasi. (2020, in Indonesian). Bekasi City Population (people), 2018-2020. https://bekasikota.bps.go.id/indicator/12/29/1/ jumlah-penduduk-kota-bekasi.html

Badan Pusat Statistik Kota Tangerang. (2019, in Indonesian). Tangerang City Population Density Based on Data from the Department of Population and Civil Registry (Soul $/ \mathrm{km}^{2}$ ), 2019. https:// tangerangkota.bps.go.id/indicator/12/180/1/ ke padatan-penduduk-kota-tangerangberdasarkan-data-dinas-kependudukan-dancatatan-sipil.html

Badan Pusat Statistik Provinsi DKI Jakarta. (2021, in Indonesian). Population, Population Growth Rate, Distribution of Population Percentage Population Density, Population Gender Ratio by Province/ District/City 2018-2020. https://jakarta.bps. go.id/indicator/12/124/1/3-1-1-penduduk-lajupertumbuhan-penduduk-distribusi-persentasependuduk-kepadatan-penduduk-rasio-jeniskelamin-penduduk-menurut-provinsi-kabupatenkota-kecamatan.html

Cordova, M.R., \& Nurhati, I.S. (2019). Major sources and monthly variations in the release of landderived marine debris from the Greater Jakarta area, Indonesia. Scientific Reports, 9(1), 1-8. https://doi.org/10.1038/s41598-019-55065-2

Dinas Lingkungan Hidup Provinsi DKI Jakarta. (2021, in Indonesian). Trends in Bantargebang TPST based on the average weight of waste per day (tons/day). https://upstdlh.id/tpst/data

Jasmin, H.H., Purba, N.P., Harahap, S.A., Pranowo, W.S., Syamsudin, M.L., \& Faizala, I. (2019). the Model of Macro Debris Transport Before Reclamation and in Existing Condition in Jakarta Bay. Jurnal IImu dan Teknologi Kelautan Tropis, 11(1), 131-140. https://doi.org/10.29244/jitkt. v11i1.24777

Kementerian Lingkungan Hidup dan Kehutanan. (2021). 
TIMBULAN SAMPAH. https://sipsn.menlhk.go.id/ sipsn/public/data/timbulan

Rositasari, R., Puspitasari, R., Nurhati, I.S., Purbonegoro, T., \& Yogaswara, D. (2017, in Indonesian). Oceanographic Research in Jakarta Bay 1970-2015. Jakarta : Puslit Oseanografi LIPI.

Sampono, N., Purbayanto, A., Haluan, J., Fauzi, A., \& Wiryawan, B. (2012). Impact of Reclamation on Capture Fisheries in Jakarta Bay. Jurnal Perikanan dan Kelautan, 2(2), 105-112. https:// doi.org/10.33512/jpk.v2i2.27

Setiawan, A. (2016, in Indonesian). Technical Report for Hydrodynamics and Geomorphology Reclamation Activity Study Team of Balitbang KP: Simulation of Hydrodynamics and Thermal Dispersion Models in Pre- and Post-Reclamation Jakarta Bay 17 Islands. Jakarta : Pusat Penelitian dan Pengembangan Sumber Daya Laut dan Pesisir - BRSDMKP, KKP. https://doi. org/10.13140/RG.2.2.23290.08642

Setiawan, A., Putri, M. R., \& Riyadi, A. (2006, in Indonesian). Transport model for the distribution of waste in Jakarta Bay. Jurnal Hidrosfir Indonesia, 2(3), 2-5.

Supangkat, S., \& Herdiansyah, H. (2020). Analysis Correlation of Municipal Solid Waste Generation and Population: Environmental Perspective. IOP Conference Series: Earth and Environmental Science, 519(1). https://doi.org/10.1088/17551315/519/1/012056

Zulfinar, Z., \& Sembiring, E. (2015, in Indonesian). The Dynamics of the Amount of Waste Produced in the City of Bandung. Jurnal Tehnik Lingkungan, 21(1), 18-28. https://doi.org/10.5614/jtl.2015.21.1.3 
Modeling of Plastic Debris Particle ...... Post Reclamation In Jakarta Bay (Winardi, E.A., et al.) 